\title{
Towards a New Form of Undemocratic Capitalism: Introducing Macro-Equity to Finance Development Post COVID-19 Crisis
}

\author{
Arvind Ashta \\ CEREN EA 7477, Burgundy School of Business, Université Bourgogne Franche-Comté, 21000 Dijon, France; \\ Arvind.ashta@bsb-education.com
}

Citation: Ashta, Arvind. 2021.

Towards a New Form of

Undemocratic Capitalism:

Introducing Macro-Equity to Finance Development Post COVID-19 Crisis.

Journal of Risk and Financial

Management 14: 116. https://

doi.org/10.3390/jrfm14030116

Academic Editor: Michael McAleer

Received: 23 February 2021

Accepted: 8 March 2021

Published: 11 March 2021

Publisher's Note: MDPI stays neutral with regard to jurisdictional claims in published maps and institutional affiliations.

\begin{abstract}
Sustainable Development Goal 16 talks about Peace, Justice, and Strong Institutions, and goal 10 talks about reducing inequality. A major problem exposed by the COVID-19 crisis is that public deficits seem to be the normal state in the business cycle's booms and downturns, limiting capacity for emergencies. Corporate capitalism has an incentive to perpetuate deficits to increase growth, provide risk-free interest income to financial institutions, and to increase inequalities and economic injustice. To counter this problem, the purpose of this communication is to suggest that countries need to issue equity capital, which we term macro-equity. This macro-equity will give dividends to its shareholders in times of public surplus and issue new shares in times of public deficits. The communication is written as a mind experiment, debating the issues that may arise. This proposal raises many questions of an ethical and moral nature that will lead to passionate debate. The use of macro-equity will reduce countries' stress, created by high public debt. With appropriate incentives, it may create an entrepreneurial mindset in political leaders that may even reduce corruption and promote redistribution. The moral and ethical issues need to be weighed against the street violence in the absence of any change.
\end{abstract}

Keywords: capitalism; public debt; public finance; inequality; macro-equity; political entrepreneurship; macroeconomic risk

\section{Introduction: The Problem of Democratic Capitalism}

A first inherent tension in democratic capitalism is its tendency to centralize firms' monopolistic power, with governments attempting to break the monopolies from time to time. It has been a losing battle for democracy, and for some time, we have been talking about corporate capitalism and corporatocracy and their problems (Blanc 2014; Karadjov 2019). In these diverse forms of monopolistic capitalism, large firms control the economy, the politicians, the legislation, and indirectly, the people. Perhaps democracy, as we knew it, remains for the sake appearances. The COVID-19 crisis has heightened the awareness of the importance of economic life and of firms' survival and perhaps legitimized the shift of power towards capital. Street violence may reflect the masses' frustration at this shift of power, as inequalities have increased (Chan 2015; Piketty 2014; Stiglitz 2013). This increase in social inequalities has been heightened during the pandemic both at a local level (Dzigbede et al. 2020) and at a global level since developing countries are unequipped to deal with this crisis.

A second inherent tension in democratic capitalism is that the state is encroaching on the private sector. This encroachment manifests in the fear of big brother and constant surveillance (Orwell 2009), which in turn leads to reminders that ignoring the private sector will lead to serfdom (Hayek 2014). These reminders lead to political conservatives like Reagan and Thatcher trying to reduce the size of the State by privatizing, outsourcing, and devolving to lower levels of government (Osborne and Plastrik 1997). The Orwellian fear was again witnessed during the Covid crisis when governments asked people to download apps that would monitor their movements and contacts. People consider that we need to beware of the State. 
To finance the COVID-19 and to relaunch the economy, governments have been spending lavishly. The public spending stimuli have focused on giving money directly to the consumers (democratic) and providing subsidies or tax-deferrals to firms (capitalistic). This balance between democracy and capitalism may move further towards the latter if public deficits mean taking debt. The collective people will then be increasingly indebted to the large banks, corporations, and international investors. The global debt was estimated to be $\$ 277$ trillion (365\% of global GDP) by the end of 2020 (IIF 2020). The interest on this debt must be serviced, in good times and bad, thus cumulating public deficits and creating stress. Lebanon is the latest case of a State succumbing to debt. Figure 1 below shows that even in developed countries, debt increased significantly in the first three quarters of 2020 by more than $10 \%$ of GDP. This massive increase in debt is enigmatic of both the underlying tensions: a more significant State controlled by more giant corporations and financers, with less room for private enterprise.

\section{Quarterly general government gross debt}

\section{(\% of GDP)}

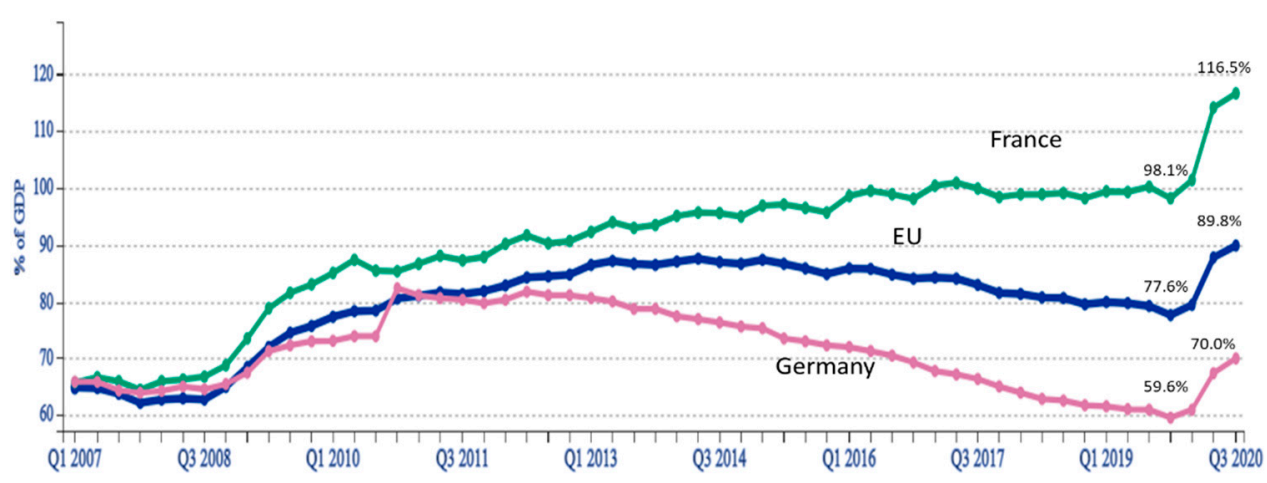

Figure 1. Debt to GDP percentage for EU, France and Germany. Source: EU Statistics.

The problem of servicing debt is especially acute if the debt is from foreign investors and denoted in hard currency, especially if the local currency depreciates, as has long been the problem for Argentina and Venezuela and, more recently, for Pakistan concerning debt from China. Moreover, to a large extent, most governments have not been following Keynesian recommendations of deficits during business cycle downturns and surpluses during booms. Figure 1 shows that some governments, such as Germany, managed to reduce debt percentages to the pre-financial crisis levels. Still, the average EU country had not yet returned to the pre-financial crisis levels of 2007. Others, such as France, have not been able to control their debt at all. As a result, they have not preserved economic firepower for the moments of crisis (Roberts 2020). The reason is that the system of incentives is biased in favor of taking more debt and ushering in higher growth, both of which favor banks and corporations. If we are to create a more reasonable global economy, we need to devise a system of incentives that reflects Keynesian prudence. This study's research objective is to provide a suggestion that may lead to a healthier budgetary policy, stronger institutions, lower inequalities, and thus promote peace.

\section{Materials and Methods}

The methodology we adopt is that of thought experiments. Thought experiments expose a hypothetical situation and look at possible consequences and alternatives before being experimented with in practice. There are many papers published in scientific journals based on thought experiments (Caste 1992; Eccles 2010; Elkington et al. 2006; Lucas 2003; Mankiw 2013; Margolis 1982). The method is useful to encourage debate before implementing a proposed solution. 
Of course, a thought experiment may suffer from limitations such as misrepresenting facts or suffering from logical inconsistency. For example, Margolis (1982) described a thought experiment devising mechanisms that allow individuals to influence social choice subject to a special tax designed to elicit truthful revelations of preferences. However, Brubaker (1983) considered that the thought experiment of Margolis (1982) would lead to misrepresentations of economic facts collected by U.S. administrative agencies. In general, experimental economists often believe that classical economics is a pure thought experiment without being based on facts, but the classical theory's evolution has led to many beneficial results (Börgers 1996).

\section{The Proposed Solution: Macro-Equity}

The traditional solution for overcoming the public debt problem has been to offer subsidies and debt waivers or debt postponement to developing countries. The problem with subsidies is that they do not provide incentives for growth but rather create incentives for dependency (Calderisi 2006; Easterly 2006; Moyo 2009). Debt waivers create similar problems and lower the country's risk rating. Therefore, future debt is priced at higher interest rates. A creative, innovative solution is required. Creativity often requires displacing knowledge from one field to another (De Bono 1970).

We know that since a corporate debt creates stress, bankers advise that it be accompanied by equity, which is entitled to dividends only in times of surplus. Equity can be raised even by firms who have credit rating issues. Moreover, equity shareholders often bring in guidance that may help the firm, and, often, they have a more significant say in the governance of a firm than debt holders.

This thought leads to a novel idea indicated by Ashta (2020). At a macro level, if governments are taking macro-debt, it should be accompanied by macro-equity (avoiding the term "public equity" that denotes shares of firms owned by the public). In this macroequity concept, firms and individuals would be able to purchase the shares of a country. The importance of equity is that it absorbs the shocks of crisis. There would be a dividend on these macro-equity shares in good times, but none in bad times. Therefore, in this macro-equity proposal, the country's shareholders would get dividends only in years when there is a public surplus.

This proposal then creates an auto-correction mechanism in line with Keynesian thinking. To increase dividends, the owners of macro-equity would like more shares and a higher payout ratio. In good times they would get higher dividends, and in bad times, they would receive more shares. This dual strategy means that these large investors would want alternate periods of deficits and surplus (Ashta 2020).

Of course, the equity does not need to be reserved for large investors. If the share price is low enough or if people can buy a part of a share as with bitcoins or many mutual funds, everybody can own a piece of their country if they want to.

\section{Discussion: Evaluating the Proposition}

As opposed to Mankiw (2013), who defends the one percent and income inequalities, the Ashta (2020) proposal is interesting because it uses the one percent's skills in creating value for the country as a whole by offering them "skin in the game" (Taleb 2018). Since Ashta (2020) indicates that this proposal opens Pandora's box, let us further develop this proposition.

First, we would suggest that a country's equity be issued in the local currency, allowing domestic investors and international investors to invest in the country. Being in a local currency, international investors would be interested in saving the currency from devaluation. They would, therefore, place pressure against any non-productive expenditure, which does not lead to a growth of their surplus. At the same time, redistribution from the rich to the poor, even unproductive pensioners, helps increase consumption and has a multiplier effect on the economy. However, redistribution towards wealthy pensioners or other unproductive people (such as renters) who cannot consume more does not support 
economic growth. Therefore, fair redistribution is beneficial to the economy, and we should expect macro-equity shareholders to be advocates of lower inequality, in line with the United Nations' sustainable development goal 10.

Of course, this multiplier effect can also result from wasteful expenditure, such as building a wall where it is not required. Still, such capital expenditure needs to be weighed against other infrastructural investments that might give higher returns. The International Monetary Fund estimates that an increase in public investment by $1 \%$ of GDP would yield a $2.7 \%$ increase in GDP of developed and emerging countries, boost private investment by $10 \%$, and employment by $1.2 \%$ in two years (IMF 2020). While one may debate the estimated figure, many developed countries need to update their depleted infrastructure failings, for which growth is unsustainable.

The second issue that we consider is whether this macro-equity proposal amounts to slavery. To respond to this issue, we can first note that firms with public equity do not treat their employees as slaves. Even in small firms where ownership and management are combined, and the perception of exploitation (in the Marxist sense) may be more significant, the employees are free to leave, whereas slaves are not. Second, at a country level, the citizens of a nation can vote with their feet. The large-scale legal and illegal immigration that we have witnessed in the last century indicates that the slavery issue would be a false issue.

Third, some developing countries may consider the possibility of foreign nationals owning their shares as neo-colonization or neo-imperialism (Nkrumah 1965; Petras and Veltmeyer 2000). However, the political interventions by wealthy oil corporations and States defending some of the African countries already indicate that neo-colonization is present. So, on the one hand, the form of neo-colonization may be important. On the other hand, direct shareholding leads to transparency. It may mean that foreign shareholders would like higher dividends from the country and may seek to add value to the host countries and not just divert value to their home country. For this, they may need a guide, as do private equity holders, business angels, and even crowdfunding investors. While the former like to control, the latter two do not. A possible suggestion would be to limit any individual or firm's ownership in a country's shares, but private equity has its advantages too.

Fourth, the reflection on private equity leads to a further thought: if private equity offers appropriate incentives to political leaders, perhaps they can be incentivized to create growth and economic welfare. These incentives would then reduce the need to capture informal economic rents in the form of bribery and corruption, which remain major obstacles to development in many countries (Ashta and Fall 2012; Liu and Dong 2020). The fight against corruption requires an understanding of the institutional logics and a creation of incentives (Misangyi et al. 2008). The previous literature has focused on the role of social entrepreneurs to reduce corruption (Maak and Stoetter 2012; Mària and Arenas 2009) and has not examined the possibility of mobilising markets to achieve this.

If private equity creates appropriate incentives, political leaders would then have an entrepreneurial mindset and this may even lead to experimentation and diffusion of good practices. This mindset would go with the thought that the State's services should be entrepreneurial and customer-oriented (Osborne and Plastrik 1997). Creating an entrepreneurial culture of learning and experimentation is essential for developing countries (Ashta and Mor 2017). Charismatic leaders would then be followed by others in the country, boosting development further. The academic literature uses the term political entrepreneur interchangeably. Some authors use it for firms that influence political policy (Weiser 2008; Yoffie and Bergenstein 1985; Gao 2008). Others use it for governments or administrations to behave entrepreneurially (Blumenthal 2009; Cumming 2018; Kosack 2014; Nollert and Schief 2011; Schneider and Teske 1992). Some academics refer to the former as corporate political actors (Yoffie and Bergenstein 1985; Gao 2008), who influence public policy in their firm's interests. For our purposes, we could call the investors in 
macro-equity as investor political actors and reserve the term political entrepreneurs for governments that behave entrepreneurially.

Fifth, Ashta (2020) indicates that affluent investors would own the country more overtly than they do at present. These rich investor political actors could include large banks as well as firms (Stiglitz 2013; Clements 2014). They would then clearly be able to modify laws in their favor even more quickly than at present. As opposed to this, there is evidence that thanks to the increased availability of information, a growing number of impact investors are targeting socially responsible firms. Moreover, there is growing evidence that firms engaging in social responsibility are also sustainable (Popescu and Popescu 2019). At the same time, there has been an increase in management theories and concepts in this field, such as Strategic Corporate Responsibility (Bowman and Haire 1975; Brooks 2005), Instrumental Stakeholder theory (Jones 1995; Jones et al. 2018), and Creating Shared Value (Porter and Kramer 2011). Many of these concepts are similar and overlapping (Crane et al. 2014), but their ensemble validates an observation that firms could improve society.

Keeping this debate in mind, we suggest using a stakeholder management approach for public governance also. Following this approach, the representatives of people, the macro-equity shareholders, and the macro-bond holders would all participate in the country's public governance. Such stakeholder arrangements work in cooperatives that function democratically and in many large corporations with supervisory boards that include employees. At the level of a firm, companies inviting public equity lose control of their firm to some extent. Therefore, some firms consider it advantageous to seek public equity, and other firms prefer to remain private. At the level of a country also, some countries may seek macro-equity, and others may not. Countries in deep trouble, the so-called "failed nations," may be the first to start initial experimentation because they seek risks since they have nothing to lose, as suggested by loss aversion theory (Camerer 2005; Kahneman and Knetsch 1991; Thaler et al. 1997). However, for the idea to be given a fair chance, a country closer to the median in living standards should test it.

Sixth, firms take debt because shareholders benefit from the tax shield, which reduces the interest burden created by debt. Since governments do not tax themselves, they do not need to take high debt to provide this tax shield. Therefore, there is less reason to favor debt over equity.

\section{Concluding Remark}

In this paper, we have further developed a case for macro-equity for countries: equity shareholders of a country would get dividends in times of public surplus and could buy more new shares in public deficits. As opposed to Ashta (2020), who proposed this solution, the contribution of this paper is to discuss how this policy proposal could affect society and institutions.

The principal advantage is that macro-equity will reduce countries' stress created by high public debt. A second advantage is that with appropriate incentives accompanying this proposal, it may lead to an entrepreneurial mindset in political leaders, reduce corruption, and better transparency. Third, the large shareholders would be in positions like business angels and venture capitalists and may provide appropriate guidance and governance to improve developing countries' institutions and economic performance.

Indeed, this idea's ethics and morality need extensive discussion before we rush in, and our contribution is still only a start. Future researchers need to examine whether people would like their country to be owned or controlled by a few wealthy people or corporates? What if foreigners buy the shares? Would the Americans accept holdings by the Chinese? Would people from Burundi like an American corporation owning shares in their country? Besides the public governance issues, international law and international taxation issues of such a proposal also need to be extensively discussed, even if it is a mere theoretical exercise. 
The COVID-19 pandemic may be a blessing if the reflections on why we are alive, the good that we can do, and the society we would like to live in, take a positive turn in helping the global masses. Public finance is meant to add grease to the public service mechanism once the primary intention is manifest. Whether tax, debt, transfers, or disinvestments, most of such existing solutions will not make a difference to the growing inequalities crippling further economic development. Innovative ideas are required. The violence breaking out on the streets is like a black mirror, foretelling where our society is heading. This violence compels a discussion of innovative ideas to create peace by ushering in economic and social justice through institutions that are better aligned with all the stakeholders, not just the elites. The results of such a discussion would be in line with Sustainable Development Goal 16: Peace, Justice and Strong Institutions and Goal 10 on reducing inequalities.

Funding: This research received no external funding.

Conflicts of Interest: The author declare no conflict of interest.

\section{References}

Ashta, Arvind, and Ndyey Salimata Fall. 2012. Institutional analysis to understand the growth of microfinance institutions in West African Economic and Monetary Union. Corporate Governance 12: 441-59. [CrossRef]

Ashta, Arvind, and Surender Mor. 2017. Fostering Well-Being through Cultural Change: Lessons from Microfinance for Social Entrepreneurs. In Good Governance and Growth in the Global Economy. Edited by Anil Kumar Sinha, Amiya Kumar Mohapatra and Tushar Sankar Banerjee. New Delhi: Bloomsbury, pp. 21-30.

Ashta, Arvind. 2020. Reflections on the financing of Covid-19? Introducing MACRO-Equity and opening Pandora's Box. Artha 6: 15-21.

Blanc, Sandrine. 2014. Expanding Workers 'Moral Space': A Liberal Critique of Corporate Capitalism. Journal of Business Ethics 120: 473-88. [CrossRef]

Blumenthal, David. 2009. Portrait of a Policy and Political Entrepreneur. Health Affairs 28: w1037-39. [CrossRef] [PubMed]

Börgers, Tilman. 1996. On the relevance of learning and evolution to economic theory. Economic Journal 106: 1374-85. [CrossRef]

Bowman, Edward H., and Mason Haire. 1975. A Strategic Posture toward Corporate Social Responsibility. California Management Review 18: 49-58. [CrossRef]

Brooks, Simon. 2005. Corporate social responsibility and strategic management: The prospects for converging discourses. Strategic Change 14: 401-11. [CrossRef]

Brubaker, Earl R. 1983. On the Margolis' thought experiment,' and the applicability of demand-revealing mechanisms to large-group decisions. Public Choice 41: 315-19. [CrossRef]

Calderisi, Robert. 2006. The Trouble with Africa: Why Foreign Aid Isn't Working. New York: Palgrave Macmillan.

Camerer, Colin. 2005. Three Cheers-Psychological, Theoretical, Empirical—For Loss Aversion. Journal of Marketing Research (JMR) 42: 129-33. [CrossRef]

Caste, Nicholas J. 1992. Drug Testing and Productivity. Journal of Business Ethics 11: 301-6. [CrossRef]

Chan, Sewin. 2015. The Next Coming Crisis of Capitalism. Public Administration Review 75: 492-96. [CrossRef]

Clements, Jeffrey D. 2014. Corporations Are Not People: Reclaiming Democracy from Big Money and Global Corporations. San Francisco: Berrett-Koehler Publishers.

Crane, Andrew, Guido Palazzo, Laura J. Spence, and Dirk Matten. 2014. Contesting the Value of "Creating Shared Value". California Management Review 56: 130-53. [CrossRef]

Cumming, Gordon D. 2018. Towards an enhanced understanding of aid policy reform: Learning from the French case. Public Administration $\mathcal{E}$ Development 38: 179-89. [CrossRef]

De Bono, Edward. 1970. Lateral Thinking: A Textbook of Creativity. London: Penguin.

Dzigbede, Komla D., Sarah Beth Gehl, and Katherine Willoughby. 2020. Disaster Resiliency of U.S. Local Governments: Insights to Strengthen Local Response and Recovery from the COVID-19 Pandemic. Public Administration Review 80: 634-43. [CrossRef] [PubMed]

Easterly, William. 2006. The White Man's Burden: Why the West's Efforts to Aid the Rest Have Done So Much Ill and So Little Good. London: Penguin Books.

Eccles, Neil. 2010. UN Principles for Responsible Investment Signatories and the Anti-Apartheid SRI Movement: A Thought Experiment. Journal of Business Ethics 95: 415-24. [CrossRef]

Elkington, John, Jed Emerson, and Seb Beloe. 2006. The Value Palette: A Tool For Full Spectrum Strategy. California Management Review 48: 6-28. [CrossRef]

Gao, Yongqiang. 2008. Institutional Change Driven by Corporate Political Entrepreneurship in Transitional China: A Process Model. International Management Review 4: 25-37.

Hayek, Friedrich. 2014. The Road to Serfdom: Text and Documents: The Definitive Edition. London: Routledge. First published by 1945.

IIF. 2020. Global Debt Monitor: Attack of the Debt Tsunami. Washington: IIF. 
IMF. 2020. Fiscal Monitor: Policies for the Recovery. Washington: IMF.

Jones, Thomas M. 1995. Instrumental stakeholder theory: A synthesis of ethics and economics. Academy of Management Review 20: 404-37. [CrossRef]

Jones, Thomas M., Jeffrey S. Harrison, and Will Felps. 2018. How Applying Instrumental Stakeholder Theory Can Provide Sustainable Competitive Advantage. Academy of Management Review 43: 371-91. [CrossRef]

Kahneman, Daniel, and Jack L. Knetsch. 1991. The Endowment Effect, Loss Aversion, and Status Quo Bias. Journal of Economic Perspectives 5: 193-206. [CrossRef]

Karadjov, Boshko. 2019. Economic Freedom, Neoliberalism and Morality: From John Locke to Robert Nozick. Journal of Sustainable Development (1857-8519) 9: 115-24.

Kosack, Stephen. 2014. The Logic of Pro-Poor Policymaking: Political Entrepreneurship and Mass Education. British Journal of Political Science 44: 409-44. [CrossRef]

Liu, Yajie, and Feng Dong. 2020. Corruption, economic development and haze pollution: Evidence from 139 global countries. Sustainability 12: 3523. [CrossRef]

Lucas, Robert E., Jr. 2003. Macroeconomic Priorities. American Economic Review 93: 1-14. [CrossRef]

Maak, Thomas, and Nicolas Stoetter. 2012. Social Entrepreneurs as Responsible Leaders: 'Fundación Paraguaya' and the Case of Martin Burt. Journal of Business Ethics 111: 413-30. [CrossRef]

Mankiw, N. Gregory. 2013. Defending the One Percent. Journal of Economic Perspectives 27: 21-34. [CrossRef]

Margolis, Howard. 1982. A thought experiment on demand-revealing mechanisms. Public Choice 38: 87-91. [CrossRef]

Mària, Josep, and Daniel Arenas. 2009. Societal Ethos and Economic Development Organizations in Nicaragua. Journal of Business Ethics 88: 231-44. [CrossRef]

Misangyi, Vilmos F., Gary R. Weaver, and Heather Elms. 2008. Ending Corruption: The Interplay among Institutional Logics, Resources, and Institutional Entrepreneurs. Academy of Management Review 33: 750-70. [CrossRef]

Moyo, Dambisa. 2009. Dead Aid: Why Aid Is Not Working and How There Is a Better Way for Africa. New York: Farrar, Straus and Giroux.

Nkrumah, Kwame. 1965. Neo-Colonialism: The Last Stage of Imperialism. London: Nelson.

Nollert, Michael, and Sebastian Schief. 2011. Preventing the Retrenchment of the Welfare State: Switzerland's Competitiveness in the World Market for Protection. Competition \& Change 15: 315-35. [CrossRef]

Orwell, George. 2009. Nineteen Eighty-Four. London: Secker \& Warburg. First published by 1949.

Osborne, David, and Peter Plastrik. 1997. Banishing Bureaucracy: Five Strategies for ReinventingGovernment. Reading: Addison Wesley.

Petras, James, and Henry Veltmeyer. 2000. Globalisation or imperialism? Cambridge Review of International Affairs 14: 32-48. [CrossRef]

Piketty, Thomas. 2014. Capital in the Twenty-First Century. Cambridge: Belknap Press.

Popescu, Cristina Raluca Gh, and Gheorghe N. Popescu. 2019. An Exploratory Study Based on a Questionnaire Concerning Green and Sustainable Finance, Corporate Social Responsibility, and Performance: Evidence from the Romanian Business Environment. Journal of Risk and Financial Management 12: 162. [CrossRef]

Porter, Michael E., and Mark R. Kramer. 2011. Creating shared value. Harvard Business Review 89: 62-77.

Roberts, Alasdair. 2020. The Third and Fatal Shock: How Pandemic Killed the Millennial Paradigm. Public Administration Review 80: 603-9. [CrossRef]

Schneider, Mark, and Paul Teske. 1992. Toward a theory of the political entrepreneur: Evidence from local government. American Political Science Review 86: 737. [CrossRef]

Stiglitz, Joeseph E. 2013. The Price of Inequality: How Today's Divided Society Endagers Our Future. New York: W.W. Norton \& Company. Taleb, Nassim Nicholas. 2018. Skin in the Game: Hidden Asymmetries in Daily Life. London: Penguin Random House.

Thaler, Richard H., Amos Tversky, Daniel Kahneman, and Alan Schwartz. 1997. The Effect of Myopia and Loss Aversion on Risk Taking: An experimental Test. Quarterly Journal of Economics 112: 647-61. [CrossRef]

Weiser, Philip J. 2008. Alfred Kahn as a Case Study of a Political Entrepreneur: An Essay in Honour of his 90th Birthday. Review of Network Economics 7: 603-15. [CrossRef]

Yoffie, David B., and Sigrid Bergenstein. 1985. Creating Political Advantage: The Rise of the Corporate Political Entrepreneur. California Management Review 28: 124-39. [CrossRef] 